\title{
Efficiency measurements of c-Si solar cell using luminescent materials
}

\author{
R.A. Talewar ${ }^{1 *}$, Charusheela Joshi ${ }^{1}$ and S.V. Moharil ${ }^{2}$ \\ ${ }^{1}$ Physics Department, Shri Ramdeobaba College of Engineering \& Management, Nagpur 440013, \\ India \\ ${ }^{2}$ Department of Physics, Rashtrasant Tukadoji Maharaj Nagpur University, Nagpur 440010, India \\ *Email: charusheela_4253@yahoo.co.in
}

Green and renewable energy is the only source capable of generating sufficient energy in order to meet the long-term energy demand worldwide [1]. The photovoltaic cells are the prime candidates for this task, since they have capacity to convert the sunlight into electricity. Currently the commercial c-Si solar cell in the market have the conversion efficiency just above $15 \%$ [2] although, theoretically the maximum efficiency can reach upto $30 \%$. Majority of the energy losses are related to the spectral mismatch of the incident solar photons energies to the energy gap of a solar cell. Spectral modification using luminescent materials has been considered as a promising option to boost the efficiency and performance of solar cells, In the present work, UV-visible to near infrared spectral converting phosphor $\mathrm{Y}_{3} \mathrm{Al}_{5} \mathrm{O}_{12}: \mathrm{Ce}^{3+}, \mathrm{Yb}^{3+}$ has been synthesized by one step combustion synthesis method. We have observed efficient down-shifting phenomenon in $\mathrm{Ce}^{3+}-\mathrm{M}^{3+}(\mathrm{Ln}=\mathrm{Yb}$ or $\mathrm{Nd})$ codoped $\mathrm{Y}_{3} \mathrm{Al}_{5} \mathrm{O}_{12}$ (YAG) phosphors through efficient energy transfer. The prepared phosphor is characterized by XRD, UV-VIS and NIR Fluorescence spectrophotometer.

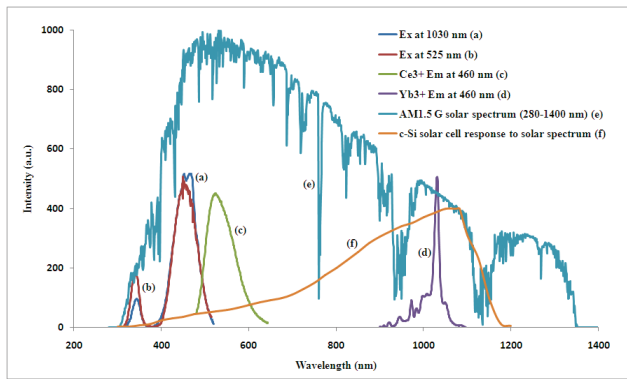

Figure 1: PLE $(a, b)$ and PL (c,d) spectra of $\mathrm{Y}_{2.943} \mathrm{Al}_{5} \mathrm{O}_{12}$ : (e) AM $1.5 \mathrm{G}$ solar spectrum and (f) spectral response

A broad emission around 500-650 nm attributing to $5 \mathrm{~d} \rightarrow 4 \mathrm{f}$ transition of $\mathrm{Ce}^{3+}$ and a very intense near infrared emission of $\mathrm{Yb}^{3+}$ at $1030 \mathrm{~nm}$ ascribing to ${ }^{2} \mathrm{~F}_{5 / 2}-{ }^{2} \mathrm{~F}_{7 / 2}$ transition was observed upon the excitation of $\mathrm{Ce}^{3+}$ at $460 \mathrm{~nm}$. An efficient energy transfer mechanism from $\mathrm{Ce}^{3+}$ to $\mathrm{Yb}^{3+}$ is also proposed (Figure 1).

c-Si solar cell module was then coated with a thin film prepared by dispersing YAG in epoxy resin. The solar cell was illuminated by solar simulator with and without coating of the thin film of phosphor prepared by us. I-V characteristics and External quantum efficiency of the module were measured and compared with the bare c-Si solar cell module. Current density of the module with and without luminescent material was calculated and found to be $14.37 \mathrm{~mA}$ and $35.05 \mathrm{~mA}$ respectively. Efficiency of the module with and without luminescent material was found to be $6.9 \%$ and $16 \%$.

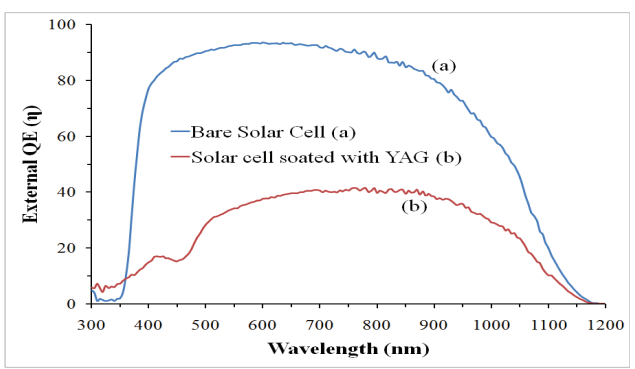

Figure 2: External Quantum Efficiency (EQE) (a) Bare solar cell (b) with $\mathrm{Y}_{2.943} \mathrm{Al}_{5} \mathrm{O}_{12}: \mathrm{Ce}, \mathrm{Yb}$

Though there is apparent drop in efficiency, the peak in Figure 2 (b) near $430 \mathrm{~nm}$ shows the absorption by YAG particles. These results demonstrate that the effect of luminescent materials was observed in the EQE curve. The drop in efficiency could be because of the shadowing effect of the phosphor particles in the film. Further ball milling and making the film transparent are being investigated.

\section{References}

1. O. Morton, Nature 443, 19-22 (2006)

2. A. Goetzberger, C Hebling, Hans-Werner Schock, Mat. Science and Engineering R 40, (2003), 1-46 